\title{
Antibacterial Potential of Broccoli Extracts against Pseudomonas aeruginosa
}

\author{
C.J. Chandekar* \\ Department of Microbiology, S.S.E.S.A's Science College, Nagpur (MS), India \\ *Corresponding author
}

\section{A B S T R A C T}

\begin{tabular}{|c|c|}
\hline $\begin{array}{l}\text { Key wor d s } \\
\text { Broccoli, } \\
\text { Pseudomonas } \\
\text { aeruginosa, } \\
\text { Antibacterial } \\
\text { activity }\end{array}$ & $\begin{array}{l}\text { Broccoli is an edible green plant in the cabbage family and possesses antibacterial activity } \\
\text { against wide range of bacterial pathogens. In the present study antibacterial activity of } \\
\text { Broccoli extracts in Methanol and Distilled Water was evaluated against skin infection } \\
\text { causing Pseudomonas aeruginosa. Antibiotic susceptibility test showed that } 100 \% \\
\text { Pseudomonas aeruginosa strains were found to be sensitive to Meropenem followed by } \\
40 \% \text { to Cefixime. However, all the strains of Pseudomonas aeruginosa were resistant to }\end{array}$ \\
\hline Article Info & \\
\hline $\begin{array}{l}\text { Accepted: } \\
\text { 20 November } 2018 \\
\text { Available Online: } \\
10 \text { December } 2018\end{array}$ & $\begin{array}{l}\text { extracts. However, Broccoli flower extract was effective against } 60 \% \text { Pseudomonas } \\
\text { aeruginosa followed by stem extract and leaves extract } 20 \% \text { each. Phytochemical analysis } \\
\text { of Broccoli extracts showed the presence of Flavonoids, Glycosides, Saponins, Steroids } \\
\text { and Terpenoids. }\end{array}$ \\
\hline
\end{tabular}

\section{Introduction}

Broccoli is an edible green plant in the cabbage family whose large flowering head is eaten as a vegetable. The word broccoli comes from the Italian plural of broccolo, which means "the flowering crest of a cabbage", and is the diminutive form of brocco, meaning "small nail" or "sprout". Broccoli is often boiled or steamed but may be eaten raw. Broccoli is a cool-weather crop that does poorly in hot summer weather. The ingestion of appropriate amounts of vegetables is known to reduce the risk of certain diseases due to the presence of beneficial biological molecules. For example, it has been shown that broccoli has anti- obesity, anticarcinogenic, antidiabetic, antimicrobial, hepatoprotective, cardioprotective, gastro protective, antiinflamatory, anti-amnesic and immunomodulatory properties (Yang and Zhang, 2011; Mahn and Reyes, 2012; Owis, 2015; Vinha et al., 2015; Park et al., 2016). These activities are attributed to the presence of bioactive compounds such as vitamin $\mathrm{C}$, carotenoids, polyphenols, glucosinolates, sulforaphane and enzymes (e.g. peroxidases, cystine lyases), among others (Fahey et al., 2002). In particular, the concentration of these chemicals in broccoli depends on cultivation parameters, processing methods and variety of the vegetable (Fraire- Cordero et al., 2010). However, Pseudomonas aeruginosa is an opportunistic pathogen. The bacterium takes 
advantage of an individual's weakened immune system to create an infection and has the ability to produce tissue-damaging toxins. Pseudomonas aeruginosa causes urinary tract infections, respiratory infections, dermatitis, soft tissue infections, and joint infections, gastrointestinal infections and a variety of systemic infections, particularly in patients with severe burns and in cancer and AIDS patients who are immunosuppressed. Pseudomonas aeruginosa is frequently resistant to many commonly used antibiotics (Wu et al., 2011). Therefore the present study was undertaken to evaluate the antibacterial activity of Broccoli extracts against skin infection causing Pseudomonas aeruginosa.

\section{Materials and Methods}

\section{Sample collection}

Broccoli vegetables were purchased from local market and rinsed with sterile distilled water for several times to remove dirt from it.

\section{Preparation of extract of Broccoli}

Broccoli flower, Broccoli stem and Broccoli leaves were cut into small pieces and subjected to air drying under shade for one week. After drying completely it was grinded to make powder of it. A $5 \mathrm{gm}$ of each samples were dissolved in $50 \mathrm{ml}$ of solvents i.e. in Methanol and Distilled water and allowed to stand for one week with frequent shaking. After one week the solvents were filtered through Whatman Filter Paper No. 1 and concentrated to dryness under reduced pressure in a rotary evaporator and stored in sterile vials at $4^{\circ} \mathrm{C}$ until used (Sibi et al., 2013).

\section{Test organisms}

Skin infection causing Pseudomonas aeruginosa were collected from pathology laboratory in Nagpur and were identified on the basis of morphological, cultural and biochemical characteristics (Collee and Marr, 1996).

\section{Antibiotic sensitivity test}

Antibiotic sensitivity test was performed by Kirby Bauer Disc Diffusion method (Bauer et al., 1966). Five different types of antibiotics were used in the study (Table 1). Pseudomonas aeruginosa strains were grown on nutrient agar at $37^{\circ} \mathrm{C}$ for 24 hours and the colonies were suspended in sterile saline water equivalent to a $0.5 \mathrm{McF}$ Farland standard (1.5X108CFU/ml). Hi-sensitivity agar plate was uniformly seeded by adding $100 \mu l$ inoculated broth and was spread by means of spreader. The discs were placed on each inoculated Hi-sensitivity agar plate. The plates were incubated at $37^{\circ} \mathrm{C}$ for 18 hours. The diameter of the zone of inhibition was observed in $\mathrm{mm}$ and the isolates were classified as "resistant" or "sensitive" based on the standard interpretative chart according to Clinical and Laboratory Standards Institute (CLSI) guidelines (CLSI, 2007).

\section{Antibacterial activity of Broccoli extracts against $P$ seudomonas aeruginosa}

Antibacterial activity of Broccoli extracts was performed by well diffusion technique. Pseudomonas aeruginosa strains were grown overnight on nutrient agar at $37^{\circ} \mathrm{C}$, and the colonies were suspended in sterile saline water equivalent to a 0.5 McFarland standard $(1.5 \times 108 \mathrm{CFU} / \mathrm{ml})$. The suspension $(100 \mu \mathrm{L})$ was spread over the Hi-Sensitivity agar. The wells of $6 \mathrm{~mm}$ diameter were cut into the agar medium with a sterilized cork borer. Then $20 \mu \mathrm{l}$ each of the extracts were added separately into the separate wells. The plates were incubated at $37^{\circ} \mathrm{C}$ for 18 hours. The diameter of the zone of inhibition around each well was measured and recorded (Bauer et al., 1966). 


\section{Phytochemical analysis}

Phytochemical analysis of the solvent extracts of broccoli was performed by following standard procedures (Sofowara, 1993). In brief, $0.5 \mathrm{ml}$ of extract was added with a drop or two of Mayer's regent by the side of test tube and the formation of white or creamy precipitate indicates presence of alkaloids. Adding $1 \mathrm{ml}$ of extract with ammonia and conc. sulphuric acid and disappearance of yellow colour on standing indicates flavonoids. Formation of brown ring at interface by the addition $2 \mathrm{ml}$ of glacial acetic acid followed by few drops of ferric chloride solution and $1 \mathrm{ml}$ of conc. sulphuric acid to the extracts revealed the presence of glycosides. Adding few drops of neutral ferric chloride to the extract and development of dark green color indicates the presence of the phenolic compounds. Existence of froth formation during warming and vigorous shaking indicates saponins. Change of colour from violet to blue or green after the addition of $2 \mathrm{ml}$ of acetic anhydride and sulphuric acid gives positive result for steroids. Appearance of brownish green or blue black coloration after adding $0.1 \%$ ferric chloride to the cooled extract indicates tannins. Addition of $2 \mathrm{ml}$ of chloroform and $3 \mathrm{ml}$ of conc. sulphuric acid to the extract and formation of reddish brown layer at the junction of two solutions confirms terpenoids.

\section{Results and Discussion}

The present study was conducted to evaluate the effect of extracts of Broccoli extracts on Pseudomonas aeruginosa. It showed the comparative study of an extracts and antibiotic Ampicillin as a positive control and negative control (Methanol and Distilled water) against strains of Pseudomonas aeruginosa. Antibiotic susceptibility test showed that $100 \%$ Pseudomonas aeruginosa strains were found to be sensitive to Meropenem followed by $40 \%$ to Cefixime. However, all the strains of Pseudomonas aeruginosa were resistant to Amoxyclav, Carbenicillin and Piperacillin (Table 2). Antibacterial activity of Broccoli extracts showed that all Pseudomonas aeruginosa $(100 \%)$ were resistant to Distilled Water extracts. However, Broccoli flower extract was effective against $60 \%$ Pseudomonas aeruginosa followed by stem extract and leaves extract $20 \%$ each (Table 3). Phytochemical analysis of Broccoli extracts showed the presence of Flavonoids, Glycosides, Saponins, Steroids and Terpenoids (Table 4).

Table.1 Antibiotics discs used in the study

\begin{tabular}{|c|c|c|}
\hline $\begin{array}{c}\text { Sr. } \\
\text { No. }\end{array}$ & Antibiotics & Concentration \\
\hline $\mathbf{1}$ & Amoxyclav & $30 \mathrm{mcg}$ \\
\hline $\mathbf{2}$ & Carbenicillin & $100 \mathrm{mcg}$ \\
\hline $\mathbf{3}$ & Cefixime & $5 \mathrm{mcg}$ \\
\hline $\mathbf{4}$ & Meropenem & $10 \mathrm{mcg}$ \\
\hline $\mathbf{5}$ & Piperacillin & $100 \mathrm{mcg}$ \\
\hline
\end{tabular}


Table.2 Antibiotics Susceptibility test of Pseudomonas aeruginosa

\begin{tabular}{|c|l|l|l|l|}
\hline Antibiotics & \multicolumn{2}{|c|}{ R } & \multicolumn{2}{|c|}{ S } \\
\hline Amoxyclav & 5 & $100 \%$ & 0 & $0 \%$ \\
\hline Carbenicillin & 5 & $100 \%$ & 0 & $0 \%$ \\
\hline Cefixime & 3 & $60 \%$ & 2 & $40 \%$ \\
\hline Meropenem & 0 & $0 \%$ & 5 & $100 \%$ \\
\hline Piperaeillin & 5 & $100 \%$ & 0 & $0 \%$ \\
\hline
\end{tabular}

Table.3 Antibacterial Activity of Broccoli Extracts against Pseudomonas aeruginosa

\begin{tabular}{|c|c|c|c|c|c|}
\hline Extracts & Solvents & \multicolumn{2}{|c|}{ R } & \multicolumn{2}{|c|}{ S } \\
\hline \multirow{2}{*}{ Broccoli Flower } & Methanol & 2 & $40 \%$ & 3 & $60 \%$ \\
\cline { 2 - 6 } & D.W & 5 & $100 \%$ & 0 & $0 \%$ \\
\hline \multirow{2}{*}{ Broccoli Stem } & Methanol & 4 & $80 \%$ & 1 & $20 \%$ \\
\cline { 2 - 6 } & D.W & 5 & $100 \%$ & 0 & $0 \%$ \\
\hline \multirow{2}{*}{ Broccoli Leaves } & Methanol & 4 & $80 \%$ & 1 & $20 \%$ \\
\hline \multirow{2}{*}{ Negative control } & D.W. & 5 & $100 \%$ & 0 & $0 \%$ \\
\hline \multirow{2}{*}{ Positive control } & Methanol & 5 & $100 \% 0$ & 0 & $0 \%$ \\
\hline (Ampicillin) & D.W & 5 & $100 \%$ & 0 & $0 \%$ \\
\hline & Methanol & 2 & $40 \%$ & 3 & $60 \%$ \\
\hline
\end{tabular}

Table.4 Phytochemical analysis of broccoli extracts

\begin{tabular}{|l|c|c|}
\hline Phytochemicals & Methanol & Distilled Water \\
\hline Alkaloids & - & - \\
\hline Flavonoids & + & - \\
\hline Glycosides & + & - \\
\hline Phenols & - & - \\
\hline Saponins & + & - \\
\hline Steroids & + & - \\
\hline Tannins & - & - \\
\hline Terpenoids & + & - \\
\hline
\end{tabular}

Where, $+=$ Present; - = Absent 
In the present study antibacterial activity of Broccoli extracts in Methanol and Distilled Water was evaluated against skin infection causing Pseudomonas aeruginosa. Antibiotic susceptibility test showed that $100 \%$ Pseudomonas aeruginosa strains were found to be sensitive to Meropenem followed by $40 \%$ to Cefixime. However, all the strains of Pseudomonas aeruginosa were resistant to Amoxyclav, Carbenicillin and Piperacillin. Antibacterial activity of Broccoli extracts showed that all Pseudomonas aeruginosa (100\%) were resistant to Distilled Water extracts. However, Broccoli flower extract was effective against $60 \%$ Pseudomonas aeruginosa followed by stem extract and leaves extract $20 \%$ each. Farzinebrahimi et al., (2012) has reported the antibacterial activity of leaf extracts of broccoli against Pseudomonas aeroginosa. Phytochemical analysis of Broccoli extracts showed the presence of Flavonoids, Glycosides, Saponins, Steroids and Terpenoids. In previous studies, it has been reported that broccoli crude extracts have activity against clinically significant bacteria (Hu et al., 2004; Owis, 2015).

In conclusion, the present study demonstrates antibacterial activity of Broccoli extracts against skin infection causing Pseudomonas aeruginosa. From the results, it would seem logical to predict that broccoli could prevent the ailments caused by skin infection causing Pseudomonas aeruginosa. Further, owing to its strong antibacterial activity, bioactive compounds from broccoli have scope for the possible use in pharmaceutical industries to stay away from skin infection causing Pseudomonas aeruginosa.

\section{References}

Bauer, AW., W.M. Kirby, J.C. Sherris and Turck, M. $1966 . \quad$ Antibiotic Susceptibility testing by a standardized disk method. Am. J. Clin. Pathol. 45(4): 493-496.

CLSI. 2007. Performance standards for antimicrobial susceptibility testing: 17th Informational supplement, Approved standard M100-S17, Wayne, USA. Clinical and Laboratory Standards Institute.

Collee JG. and Marr W. 1996. Tests for identification of bacteria and laboratory control of antimicrobial therapy, Chapter 7 and chapter 8. In In: Mackie \& McCartney Practical Medical Microbiology, by Fraser A.G., Marmion B.P. and Simmons (Eds.) 14th ed. Collee J.G., 131-151. New York: Churchill Livingstone: New York.

Fahey, J.W., X. Haristoy, P.M. Dolan, T.W. Kensler, I. Scholtus, K.K. Stephenson, P. Talalay and Lozniewski, A. 2002. Sulforaphane inhibits extracellular, intracellular, and antibiotic-resistant strains of Helicobacter pylori and prevents benzo[a]pyrene-induced stomach tumors. Proc Natl Acad Sci. 99: 7610-7615.

Farzinebrahimi R, R.M. Taha, M. Fadainasab and Mokhtari S. 2012. In vitro plant regeneration, antioxidant and antibacterial studies on broccoli, Brassica oleracea var italica. Pak J Bot. 44(6):2117-2122.

Fraire-Cordero, M.L., D. Nieto-Angel, E. Cardenas-Soriano, G. Guti errezAlonso, R. Bujanos-Mu niz and Vaquera-Huerta, H. 2010 Effect of varieties and plant density on the physical quality of broccoli (Brassica oleracea var. Italica). Rev Fitotec Mex. 33, 141-147.

Hu, S.H., J.C. Wang, H.F. Kung, J.T. Wang, W.L. Lee, Y.H. Yang and Kaohsiung, J. 2014. Antimicrobial effect of extracts of cruciferous vegetables. Med Sci. 20: 591-599. 
Mahn, A. and Reyes, A. 2012. An overview of health- promoting compounds of broccoli (Brassica oleracea var. italic) and the effect of processing. Food Sci Technol Int. 18: 503-514.

Owis, A.I. 2015. Broccoli; the green beauty: a review. J Pharm Sci Res. 7: 696-703.

Park, S.K., J.S. Ha, J.M. Kim, J.Y. Kang, S. du Lee, T.J. Guo, U. Lee and Kim, D.O. 2016. Antiamnesic effect of broccoli (Brassica oleracea var. italica) leaves on amyloid beta (Ab)142-induced learning and memory impairment. J Agric Chem. 64: 33533361.

Sibi G., A. Shukla, K. Dhananjaya, K.R. Ravikumar and Mallesha H. 2013. In vitro antibacterial activities of Broccoli (Brassica oleracea L. var italica) against food borne bacteria. Journal of Applied Pharmaceutical Science. 3(5): 100-103.

Sofowara A. 1993. Screening plants for bioactive agents. In: Medicinal Plants and Traditional Medicinal in Africa, second ed., Spectrum Books Ltd., Sunshine House, Ibadan, Nigeria. pp. 134-156.

Vinha, A.F., R.C. Alves, S.V.P. Barreira, A.S.G. Costa and Oliveira, M.B.P.P. 2015. Impact of boiling on phytochemicals and antioxidant activity of green vegetables consumed in the Medigreen vegetables consumed in the Mediterranean diet. Food Funct. 6: 1157-1163.

Wu, D.C., W.W. Chan, A.I. Metelitsa, L. Fiorillo and Lin, A.N. 2011. Pseudomonas skin infection: clinical features, epidemiology, and management. Am. J. Clin. Dermatol. 12(3): 157-69.

Yang, Y. and Zhang, X. 2011. In vitro antitumor activity of broccolini seeds extracts. Scanning. 33: 402-404.

\section{How to cite this article:}

Chandekar, C.J. 2018. Antibacterial Potential of Broccoli Extracts against Pseudomonas aeruginosa. Int.J.Curr.Microbiol.App.Sci. 7(12): 1690-1695. doi: https://doi.org/10.20546/ijcmas.2018.712.196 